\title{
Nitrate Pollution of Groundwater Based on GIS in the City of Daloa, West-central Cote d'Ivoire
}

\begin{abstract}
SAMPAH GEORGES EBLIN ${ }^{1}$, KOUAKOU SERAPHIN KONAN ${ }^{1}$, OI MANGOUA J ULES MANGOUAㄹ, VALENTIN NEDEFF²*, ANDREI VICTOR SANDU ${ }^{3,4}$, NARCIS BARSAN2*, ION SANDU ${ }^{3,5}$

J] ean Lorougnon Guede University, Department of Earth Sciences, Laboratory of Environmental Science and Technology, BP 150 Daloa, Cote d'Ivoire

${ }^{2}$ Vasile Alecsandri University of Bacau, Faculty of Engineering, Department of Environment Engineering and Mechanical Engineering, 156 Calea Marasesti, 600115, Bacau, Romania

${ }^{3}$ Gheorghe Asachi Technical University of Iasi, Materials Science and Engineering Faculty, 53A D. Mangeron Blvd., 700050, Iasi, Romania

${ }^{4}$ Romanian Inventors Forum, 3 Sf. Petru Movila St., Bloc L11, III/3, 700089 lasi, Romania

${ }^{5}$ Alexandru Ioan Cuza University of lasi, Arheoinvest Interdisciplinary Platform, Scientific Investigation Laboratory, 11 Carol I Blvd., 700506 lasi, Romania

Doubt about the quality of tap water, due to its color, taste and unpleasant odors, forces a large part of the population of the city of Daloa (west-central of Cote d'Ivoire) to turn to spring and traditional wells waters whose quality is unknown. This study aims to assess the level of nitrate pollution of these shallow aquifers through 29 points including 9 spring and 20 traditional wells spread all over the city. Nitrate concentrations range from $2.5 \mathrm{mg} / \mathrm{L}$ to $301.1 \mathrm{mg} / \mathrm{L}$, with $30 \%$ of the wells containing an excess of nitrate, beyond the WHO drinking standard $(50 \mathrm{mg} / \mathrm{L})$. The map of levels of nitrate concentrations in the city's wells and springs shows the exposure of the populations of the old downtown neighborhoods to a high health risk due to the high pollution potential of nitrate in the water.
\end{abstract}

Keywords: nitrate, pollution, shallow aquifers, spring, traditional wells

Large African cities are experiencing uncontrolled growth in area and demography leading to anarchic occupation of urban space. The settlement of populations in this urban space is often not followed by a basic sanitation system so that human activities threaten the quality of water resources. The mechanism of pollution of groundwater is an evolutionary process in space and time, difficult to master [1-12]. The impact of these pollutions appears in the deterioration of the quality of the water resources that become unsafe for the population in the majority of cases and even unusable for the other uses in some cases [114]. Thus the alteration of the aquifer has gradually become a global concern $[15,16]$.

The water of the Lobo River treated for the consumption of populations of the municipality of Daloa is burdened in organic matter, pollutants and other toxic substances [17]. The inefficiency of the treatment gives the tap water a colour, odours and unpleasant taste. Doubt about the quality of water, coupled with the weak distribution network [18], forces a large part of the city's population to turn to traditional well water and springs. These resources are superficial aquifers naturally exposed to all forms of pollution [19], some of which come from anthropogenic activities such as agricultural practices, uncontrolled landfills and wild sanitation [20]. On the other hand, traditional wells and domestic wastewater collection systems coexist in households, often at distances of less than $10 \mathrm{~m}$.

According to [21], globally, wastewater is the main source of pollution of groundwater resources. In addition, like cities in developing countries, wild garbage dumps abound in places $[22,23]$ and especially upstream of the lowlands, areas par excellence of emergence of spring waters of the city. In Daloa, studies of the quality of these resources are very sketchy and even non-existent [24]. Thus, there is a risk of health related to the consumption of traditional wells and springs water. This study aims to enquire about the state of this aquifer through the assessment of nitrate from 29 water points. Geographical Information System (GIS) were used to perform geographic analyses to highlight the spatial distribution map of nitrates in groundwater. Indeed, the map is necessary and unavoidable because it makes it easy to identify areas with potential health risk.

\section{Experimental part}

Study area

The city of Daloa is located in west-central Côte d'Ivoire between longitudes $6^{\circ} 24^{\prime}$ and $6^{\circ} 29^{\prime}$ West and latitudes $6^{\circ} 50^{\prime}$ and $6^{\circ} 55^{\prime}$ North (fig. 1). This an area par excellence of coffee and cocoa production. In the decades 1960-1980, vast movements of land colonization will lead to a rapid demographic growth in the region [25]. The 2014 General Population and Housing Census estimates the population of Daloa City at around 320,000.

\section{Materials and method}

This study required a digital camera for shooting and a GPS for positioning the 29 sampling points as provided by the protocol (table 1).

Traditional wells (fig. 2-a) and springs (fig. 2-b) water samples were collected in polyethylene bottles of $1 \mathrm{~L}$ capacity and stored in cooler containing dryice. Nitrate concentrations were determined by a HACH DR6000 spectrophotometer (fig. 2-c), at the Laboratory of Water Quality of the Faculty of Environment of the Jean Lorougnon Guede University of Daloa (Cote d'Ivoire). 


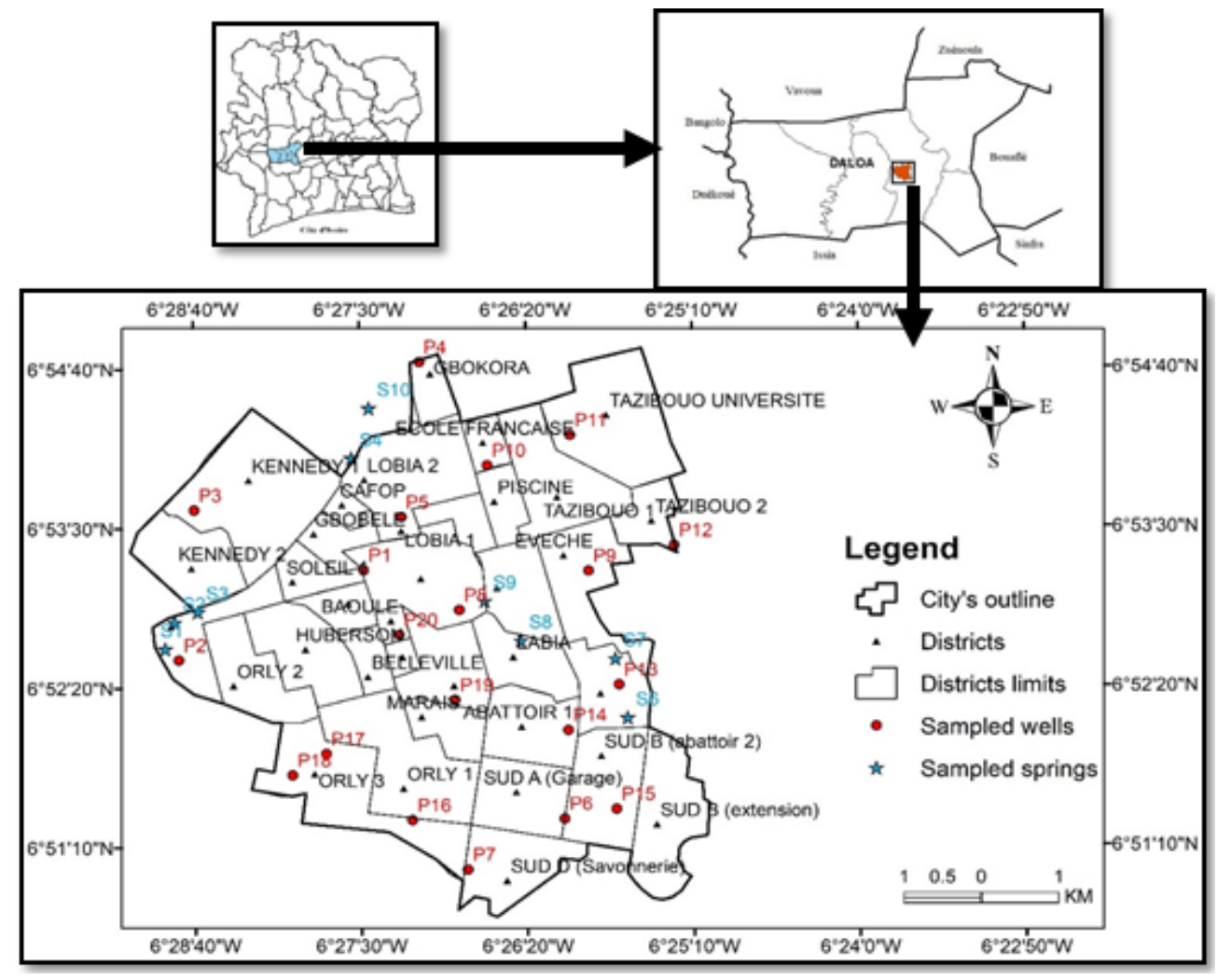

Fig. 1. Daloa City and sampling points

\begin{tabular}{|c|c|c|c|}
\hline \multirow{2}{*}{ Sampling points (i) } & \multicolumn{2}{|c|}{ UTM coordinates } & \multirow{2}{*}{$\begin{array}{c}\text { Concentrations } \\
\mathrm{Ci}(\mathrm{mg} / \mathrm{L})\end{array}$} \\
\hline & $\mathrm{Xi}(\mathrm{m})$ & $\mathrm{Yi}(\mathrm{m})$ & \\
\hline Pi1 & Xil & Yi1 & Cil \\
\hline $\mathrm{P}_{12}$ & $\mathrm{Xi2}$ & $\mathrm{Yi2}$ & $\mathrm{Ci} 2$ \\
\hline$\cdots$ & $\cdots$ & $\cdots$ & $\cdots$ \\
\hline $\mathrm{Pi} 29^{\circ}$ & $\mathrm{Xi} 29$ & Yis9 & $\mathrm{Ci} 29$ \\
\hline
\end{tabular}

Table 1

CHARACTERISTICS OF SAMPLING POINTS

In the ArcGIS 10.2 environment, Spatial Analyst Tools IDW interpolated the resulting nitrate concentrations from sampling points (known $x$, y coordinates), to elaborate the nitrate map.

\section{Results and discussions}

Nitrate concentrations obtained are sometimes very high, with a maximum value of $301.1 \mathrm{mg} / \mathrm{L}$. In spring waters, concentrations are low to moderate; except spring water near the general hospital $(49.3 \mathrm{mg} / \mathrm{L})$, which is close to the WHO drinking water guidelines $(50 \mathrm{mg} / \mathrm{L})$. On the other hand, in well waters, nitrate concentrations are sometimes very high, well above the WHO standard (table 2).

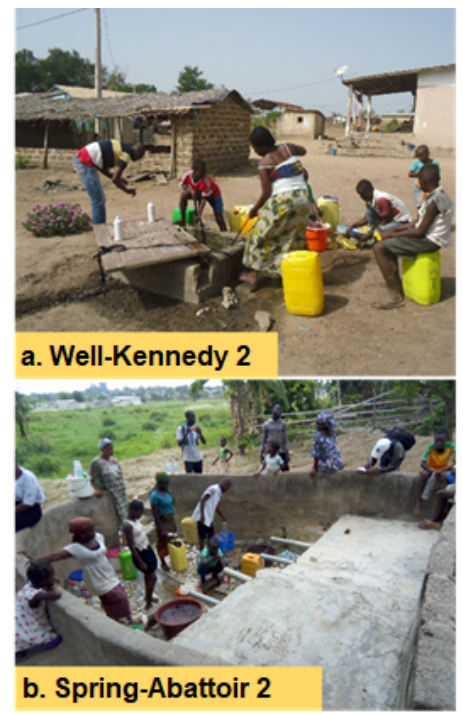

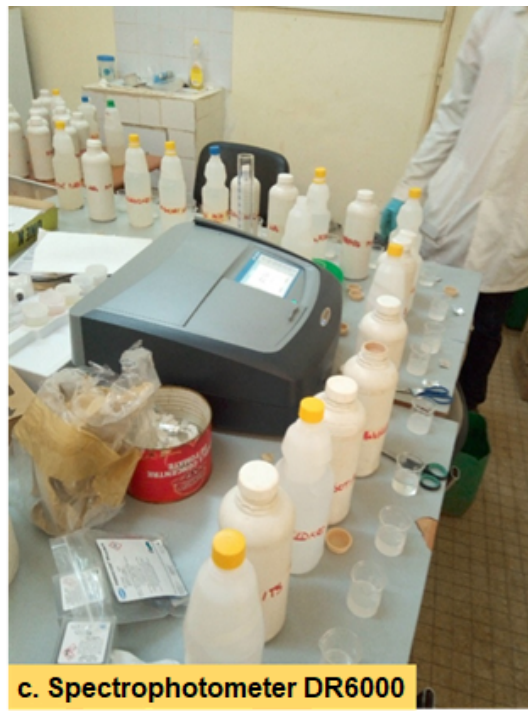

http://www.revistadechimie.ro
Fig. 2. Collection of water samples and laboratory analyses
Table 3 summarizes in 5 classes the results of nitrate concentrations obtained. Moderate concentrations (10 to $30 \mathrm{mg} / \mathrm{L}$ ) represent more than $34 \%$ of the samples; then there are the very high concentrations (over $50 \mathrm{mg} / \mathrm{L}$ ) that represents about $21 \%$ of the samples. High concentrations ( 30 to $50 \mathrm{mg} / \mathrm{L}$ ) are the least represented (more than 10\% of the samples). Low ( 5 to $10 \mathrm{mg} / \mathrm{L}$ ) and very low (0 to 5 $\mathrm{mg} / \mathrm{L}$ ) concentrations are equitably represented.

From classes of nitrate concentrations in the shallow aquifers of the city, a geographical analysis was made to obtain the spatial distribution map of nitrate in the city ( fig. 3). 


\begin{tabular}{|c|c|c|c|c|c|}
\hline Origin of water & Min & Max & Average & \multicolumn{2}{|c|}{ Standard deviation } \\
\hline Groundwater & 2.5 & $301 \backslash 1$ & $\overline{44.1}$ & \multicolumn{2}{|c|}{66.57} \\
\hline Springs & 5 & 49.3 & 17.71 & \multicolumn{2}{|c|}{14.00} \\
\hline Wells & 2.5 & 301.1 & 55.97 & \multicolumn{2}{|c|}{77.27} \\
\hline WHO standard & \multicolumn{5}{|c|}{$\leq 50 \mathrm{mg} / \mathrm{L}$} \\
\hline \multicolumn{3}{|c|}{$\begin{array}{l}\text { Classes of nitrate concentrations } \\
\qquad(\mathrm{mg} / \mathrm{L})\end{array}$} & $\begin{array}{l}\text { Characteristics of } \\
\text { concentrations }\end{array}$ & $\begin{array}{l}\text { Number of } \\
\text { samples }\end{array}$ & $\begin{array}{c}\text { Frequency } \\
(\%)\end{array}$ \\
\hline \multicolumn{3}{|c|}{$\leq 5$} & Very low & 5 & 17.24 \\
\hline \multicolumn{3}{|c|}{ ]5-10] } & Low & 5 & $17.24^{-}$ \\
\hline \multicolumn{3}{|c|}{ ]10-30] } & Moderate & $10^{-}$ & 34.48 \\
\hline \multicolumn{3}{|c|}{ ]30-50] } & High & 3 & 10.34 \\
\hline \multicolumn{3}{|c|}{$>50^{-}$} & Very high & 6 & $20.69^{--}$ \\
\hline \multicolumn{3}{|c|}{ TOTAL } & & 29 & 100 \\
\hline
\end{tabular}

Table 2

ARIATION OF NITRATE CONCENTRATIONS IN THE SHALLOW AQUIFERS IN THE CITY OF DALOA

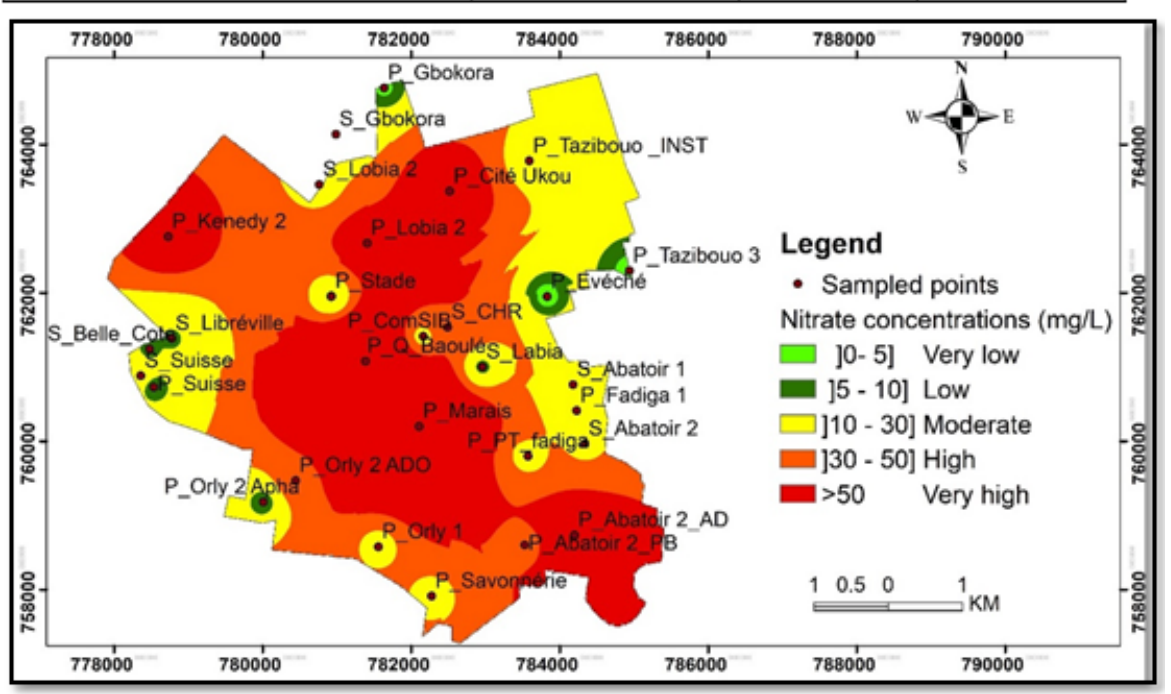

Table 3

CLASSES OF NITRATE

CONCENTRATIONS IN THE SHALLOW AQUIFERS IN THE CITY OF DALOA
Fig. 3. Spatial distribution of nitrate concentrations in the shallow aquifers in the city of Daloa
This map shows that the shallow aquifer of the city of Daloa is mostly covered by nitrate concentrations beyond the WHO drinking water standard ( $40 \%$ of the total surface area); then come the high concentrations (33\% of the study area) and moderate concentrations (25\%) (fig. 4). Low and very low nitrate concentrations cover insignificant surfaces and are generally obtained in the peripheries that represent the extension areas of the city (fig. 3).

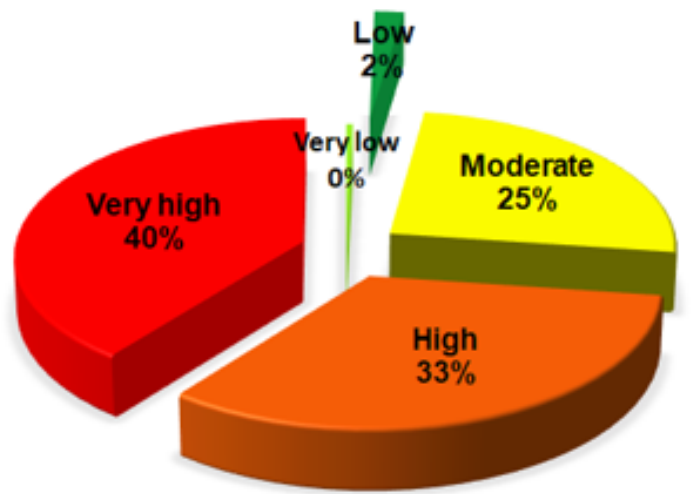

Fig. 4. Spatial division of nitrate concentrations in the shallow aquifers in the city of Daloa

Agriculture is considered to be the main cause of the increase in the concentrations of phytosanitary products in the receiving environment, the first emitter of nitrogen pollution and the second emitter of phosphorus [26]. Therefore the high nitrate concentrations in well water could be justified byintense agricultural activity in the region of Daloa. How ever, very $(17 \%)$ to low $(17 \%)$ nitrate concentrations were observed in some wells. On the other hand, the high standard deviation (77.27 mg/L) between the extreme values shows that this parameter evolves significantly from one well to another. It can thus be said that the impact of agriculture is not considerable on the superficial aquifers of the city. According to [27], maximum nitrate concentrations are not necessarily located under agricultural parcels. In some cases, the contribution of septic tanks can cause nitrate pollution greater than agriculture [28]. Indeed, rapid poorly controlled urbanization contributes to nitrate pollution of groundwater [29].

In Daloa, wells are generally dug in households that lack sanitation. Toilet waters and greywater (sinks, kitchen, washing machine, shower, etc.) are respectively discharged into septic tanks and wells lost. The study shows that contaminated areas are concerned with the town centre and are mostly represented by the old districts where domestic wastewater collection systems would fail. The condition of the old facilities raises some concerns about groundwater, which is a vital resource. These conclusions were drawn following studies carried out in the municipality of Abidjan (Cote d'Ivoire) where the nitrate concentrations obtained are very high in the old districts strongly urbanized $[30,31]$. The impact of pit latrines on the quality of groundwater has been subject of several studies [32, 33]. This study reveals sometimes very high nitrate concentrations in well waters $(21 \%)$ which confirm shallow aquifers pollution in the city of Daloa by domestic wastewater. Highly variable concentrations depend on a 
number of factors including the water level in the well and the location of wells in relation to endogenous sources of contamination [19,34].

For drinking water, the limit value of nitrate concentration is $50 \mathrm{mg} / \mathrm{L}$; beyond that, its poses health risks. In fact, consumption of water that is highly contaminated with nitrates can lead to various health problems [35, 36], such as methemoglobinemia, gastric cancer, goiter, congenital malformations, hypertension, etc. An article published in 2008 by [37] mentions that between 1945 and 1970, nearly 2000 cases of methemoglobinemia were reported in the world literature; most of these cases being associated with the consumption of private well water with a high concentration of nitrates. It is safe to say that the users of these wells are exposed to health risks. A study conducted by [18] at the Orly district of Daloa, to establish a relationship between water supply patterns and population health, showed that $64.03 \%$ of waterborne diseases would be associated with the consumption of well water.

\section{Conclusions}

Nitrate concentrations in shallow aquifers in the city of Daloa range from 2.5 to $301.1 \mathrm{mg} / \mathrm{L}$ with an average of $44.1 \pm 66.57 \mathrm{mg} / \mathrm{L}$. In spring waters, they range from 5 to $49.3 \mathrm{mg} / \mathrm{L}$ with an average of $17.71 \pm 14.00 \mathrm{mg} / \mathrm{L}$. Extreme concentrations are obtained in well water with an average of $55.97 \pm 77.27 \mathrm{mg} / \mathrm{L}$. These results show that the high $(10 \%)$ and very high $(21 \%)$ nitrate concentrations obtained in the sampled wells are attributable to pollution of the water table by discharges of domestic effluents, especially septic tanks. These wells pose a public health risk because excess nitrates in drinking water can be at the origin of many diseases mentioned in the literature. It is therefore imperative to proceed with their immediate closure.

The resulting map is a decision support tool that can allow authorities to anticipate a health disaster.

Acknowledgements: We thank the Project: Support to the Modernization and Reform of Universities and Large Schools of Côte d'Ivoire (AMRUGE-CI) for funding the research project titled " Development of an integrated water resources management model for the improvement of drinking water supply in the municipality of Daloa » of the faculty of Environment of J ean Lorougnon Guede University. The data in our possession comes from the execution of this project whose coordinators have made us responsible for leading the Water Quality team. We also thank the Francophony University Agency (AUF) for the mobility grant we benefited from. Our research trip to the Laboratory of Water Quality and Wastewater of the Faculty of Engineering of Vasile Alecsandri University of Bacau (Romania) allowed us to share knowledge and experiences with our Romanian colleagues.

\section{References}

1. CHITIMUS, A.D., MOSNEGUTU, E., NICOLESCU, M.C., TURCU, M., BELCIU, M.C., ARDELEANU, G., Environmental Engineering \& Management J ournal, 13, no. 7, 2014, p. 1581.

2. CHITIMUS, A.D., RADU, C., NEDEFF, V., MOSNEGUTU, E., BARSAN, N., Scientific Study \& Research Chemistry \& Chemical Engineering, Biotechnology, Food Industry, 17, no. 4, 2016, p. 381.

3. CHITIMUS, A.D., BARSAN, N., NEDEFF, V., MOSNEGUTU, E., MUSCALU (PLESCAN), O., Studies and research concerning the influence of liquid pollutants' leaching speed in the soil on the process of cleaning and self-cleaning, 17th International Multidisciplinary Scientific GeoConference SGEM 17, 17, no. 51, 2017, p. 859.

4. RADU, C., CHITIMUS, A.D., TURCU, M., ARDELEANU, G., BELCIU, $M .$, Environmental Engineering and Management J ournal, 13, no. 7, 2014, p. 1687.

2582
5. CHITIMUS, A.D., NEDEFF, V., MOSNEGUTU, E., PANAINTE, M., Environmental Engineering and Management J ournal, 11, no. 12, 2012, p. 2163.

6. MUSCALU (PLESCAN), O.M., NEDEFF, V., CHITIMUS, A.D., PARTAL, E., MOSNEGUTU, E., RUSU, I.D., Rev. Chim. (Bucharest), 69, no. 11, 2018, p. 3106.

7. CHITIMUS D., COCHIORCA A., NEDEFF V., MUSCALU O., BARSAN N., Studies and Research on Phragmites Australis' (Common Reed) Absorption Capacity of Heavy Metals From the Soil in Roman City, Romania, Proceeding of the International Multidisciplinary Scientific GeoConference Surveying Geology and Mining Ecology Management, SGEM 18, 18, 2018, p. 671-678.

8. MUSCALU (PLESCAN) O.M., NEDEFF V., CHIIMUS, A.D., PARTAL E., BARSAN N., RUSU I.D., Rev. Chim. (Bucharest), 70, no. 2, 2019, p. 536. 9. MOSNEGUTU, E.F., NEDEFF, V., CHITIMUS, A.D., RUSU, D.I., International J ournal of Conservation Science, 10, no. 1, 2019, p. 131. 10. COCHIORCA, A., NEDEFF, V., BARSAN, N., PANAINTE-LEHADUS, M., MOSNEGUTU, E. F., Aspects related to water quality assessment in a mining activity area. Case study, mining area Tg. Ogna, Romania, Proceeding of the International Multidisciplinary Scientific GeoConference Surveying Geology and Mining Ecology Management, SGEM, 18, no. 3.1, 2018, p. 87.

11. COCHIORCA, A., NEDEFF, V., BARSAN, N., MOSNEGUTU, E.F., PANAINTE-LEHADUS, M., TOMOZEI, C., Chemistry \& Chemical Engineering, Biotechnology, Food Industry, 19, no 4, 2018, p. 455.

12. ABDELBAKI, C., BOUKLI, H.F., Revue des Energies Renouvelables, 10, no. 2, 2007, p. 257.

13. KEDDAL, H., N'DRI, Y.J., Revue HTE, 1, no. 138, 2008, p. 13.

14. SHAHBAZI, A., ESMAEILI-SARI, A., World Applied Sciences J ournal, 5, 2009, p. 92.

15. BERDAI, H., SOUDI, B., BELLOUTI, A., Revue HTE, no. 128, 2004, p. 65.

16. IDRISSI, L., Nitrates and nitrites: Pollutants that threaten health and the environment, Les Technologies de Laboratoire, 1, 2006, p. 10.

17. LABE, S., JOURDA, J.P., SALEY, M.B., YOUAN, T.M., LASM, T., KOUADIO, B.H., J ournal International Sciences et Technique de I'Eau et de l'Environnement, 3, no. 1, 2018, p. 38.

18. AWOMON, D.F., COULIBALY, M., NIAMKE, G.M., SANTOS, D.S., Revue Espace, Territoires, Societes et Santé, 1, no. 2, 2018, p. 91.

19. TEMPLETON, M.R., HAMMOUD, A.S., BUTLER, A.P., BRAUN, L., FOUCHER, J-A., GROSSMANN, J., BOUKARI, M., FAYE, S., JOURDA, J.P., AIMS Environmental Science, 2, no. 2, 2015, p. 302.

20. BABIKER, I.S., MOHAMED, M.A.A., HIYAMA, T., KATO, K., Science of the Total Environment, 345, no. 1-3, 2005, p. 127.

21. BEAUCHAMP, J., Coastal Pollution, DESS Quality and Water Management (in French), Université de Picardie J ules Verne (France), 2003, p. 30.

22. BEN AMMAR, S., FOULLY, B., Techniques Sciences Méthodes, $\mathbf{4}$, 2008, p. 97.

23. ZAHRANI, F., NAQUIN, P., NGNIKAM, E., Revue Francophone d'Ecologie Industrielle, 43, 2015, p. 31.

24. LIGBAN, R., GONE, L.D., KAMAGATE, B., SALEY, M.B., BIEMI, J., International J ournal of Biology and Chemical Science, 3, no. 1, 2009, p. 38.

25. YAO, A.B., GOULA, B.T.A., KOUADIO, Z.A., KOUAKOU, K.E., KANTE, A., SAMBOU, S., Revue Ivoirienne des Sciences et Technologie, 19, 2012, p. 136.

26. BENDRA, B., FETOUANI, S., SBAA, M., GHARIBI, E., EL HALOUANI, $\mathrm{H}$., RHOMARI, Y., Study of the impact of diffuse agricultural pollution on the quality of water and soil in the Triffa Plain (in French), 3rd International Days of Environmental Geosciences, El Jadida, June 8, 9 and 10, 2005. Communication displayed, 2005, p. 1.

27. BARREZ, F., Tests for vertical hydrochemical characterization of the chalk aquifer in the mining sector Carvin-Douai-Henin Beaumont, (in French), PhD Thesis, University of Lille 1, France, 2006, $144 \mathrm{p}$. 28. NAWAB, B., ESSER, K.B., BAIG, S.A., Environmental Forensics, 18, no. 4, 2017, p. 296. 
29. J OURDA, J.P., KOUAMÉ, K.J ., SALEY, M.B., KOUAME, K.F., KOUADIO, B.H., KOUAMÉ K., A new cartographic approach to determine the groundwater vulnerability of the Abidjan aquifer, In Groundwater Pollution in Africa, Xu Y, Usher B (eds), Taylor \& Francis/Balkema: Leiden, 2006, p. 103.

30. AHOUSSI, K.E., LOKO, S., KOFFI, Y.B, SORO, G., OGA, Y.M.S, SORO, N., International J ournal of Pure \& Applied Bioscience, 1, no. 3, 2013, p. 45.

31. SORO, N., OUATTARA, L., DONGO, K., KOUADIO, K.E., AHOUSSI K.E., SORO, G., OGA, Y.M.S., SAVANE, I., BIEMI, J., International J ournal of Biological and Chemical Sciences, 4, no. 6, 2010, p. 2203.

32. GRAHAM, J.P., POLIZZOTTO, M.L., Environmental Health Perspectives, 121, no. 5, 2013, p. 521.

33. HAMMOUD, A.S., LEUNG, J., TRIPATHI, S., BUTLER, A.P., SULE, M.N., TEMPLETON, M.R., Environmental Science, 5, no. 3, 2018, p. 143.
34. YAPO, O.B., MAMBO, V., SEKA, A., OHOU, M.J.A., KONAN, F., GOUZILE, V., TIDOU, S.A., KOUAME, K.V., HOUENOU, P., International J ournal of Biological and Chemical Science, 4, no. 2, 2010, p. 289.

35. AFSSA (French Food Safety Agency), Sheet 19: Assessment of the health risks linked to the exceeding of the quality limits for nitrates and nitrites in water intended for human consumption, Referral, (in French), no. 2004-SA-0067, p. 55. https://www.anses.fr/fr/system/files/ EAUX-Fi-NitratesNitrites.pdf.

36. PROVOST-DUBOIS, R., MICHAUD, C., GAGNON, F., Water, source of life! Sometimes sick (in French), Santé et Environnement, 12, no. 3, 2015, p. 35. https://www.oiiq.org/sites/default/ files/uploads/ periodiques/Perspective/vol12no3/12-sante-environnement.pdf 37.***InVS (Institute of Health Watch), History, State of play, Epidemiological surveillance (in French), 2008, p. 3. http:// invs.santepubliquefrance.fr/.

Manuscript received:7.12.2018 